\title{
10 Years: Residência Pediátrica is ten!
}

\author{
Clemax Couto Sant'Anna', Marilene A. Crispino R. Santos' ${ }^{1}$, Marcia Alves Galvão ${ }^{1}$
}

\section{Years: Residência Pediátrica is ten!}

The first issue of the Residência Pediátrica was aired in April 2011. Since then, the magazine has established itself with the public of pediatric residents and related areas, as well as among pediatricians who want quick guidance for the care of their patients, to clear up doubts. conduct or expand their knowledge in a particular area.

At the 1st Brazilian Congress of Resident Doctors in Pediatrics in $2010^{1}$, our editor Dr. Marilene A. C. Santos and our late collaborator Dr. Gil Simões Batista, envision the possibility of creating a journal with a peculiar characteristic: aimed at pediatric residents. The following year, RP was launched. One of the few magazines aimed at residents and perhaps the only one aimed at pediatric residents.

We have dedicated collaborators. Many of them continue to offer us the opportunity for good readings in various fields of pediatric knowledge. Our warm thanks to all. We are going to honor two of them, on behalf of the others: Dr Sandra Amaral, who for a decade kept the Caso Interativo in the magazine and who always aroused great interest from readers. Another section maintained for a long time was the TOP (Mandatory Topics in Pediatrics), created by Dr Gil.

Here we also register our tribute to the reviewers who perform a work that is almost invisible to readers, but who strive to qualify the journal, making comments, suggestions and, when necessary, rejecting articles. Yes, because the refusal based on strong arguments is also an educational action that motivates authors to always seek the best of themselves in their future publications.

Over the years, changes have been taking place and indexing has emerged. In 2018 there was a significant change, which was the publication of the RP in a continuous flow with publication in Portuguese and English. This type of publication made the dissemination of articles faster,
In 2020, right after the Pandemic took hold in the world, there was a large number of articles that aimed to update pediatricians in dealing with COVID-19. This phenomenon occurred in most scientific journals around the world, reflecting the perplexity of an unprecedented health situation that demanded new knowledge. Seeking to adapt to this reality. RP introduced the publication of articles in a pre-diagram format in the Special Edition, which was highly sought after by authors and readers. Here, we would like to thank the guest editors of the Special Edition, professors Maria de Fátima B Pombo Sant ['Anna and Dirceu Solé, who engaged in intensive work in reviewing the more than 80 articles submitted.

In 2016, when RP completed five years, it already had about 10 thousand downloads of articles monthly ${ }^{2}$. Aware that marketing strategies must be applied in order to increasingly strengthen the relationship with readers/users in scientific communication, chronologically, the RP magazine joined Facebook $^{3}$ and Twitter $^{4}$ in June 2011, Soucloud ${ }^{5}$ in March 2016 (where he publishes his Podcasts), on Linkedin ${ }^{6}$ in June 2018, and on Instagram ${ }^{7}$ in March 2019. He also published videos-classes on Youtube ${ }^{8}$ from 2011 to 2017 . Thanks to this dissemination effort, we reached one million in 2018 of hits in the magazine!

\section{How to celebrate 10 years of RP?}

In this sense, a Judging Committee was formed, composed of professors Mario Santoro Jr, Edson Liberal, Anamaria Cavalcante, Clarisse Fortes, Paulo A. Camargos and Sibelle Buonora to select the articles that will be awarded at the end of the year, as a maximum record of this celebration. Other activities are also planned.

\footnotetext{
${ }^{1}$ Scientific Editor of RP.
} 
RP has been seeking to renew itself, and update itself, while recognizing the difficulty of facing all the developments that Pediatrics is constantly undergoing. New technologies, emerging diseases, the diversity of communication vehicles and everything that the present disguised as the future brings us. As a stimulus, we have the constant training of pediatric residents, their energy, their hopes, the silent and constant renewal of medical knowledge. We wish RP many years of life!

\section{REFERENCES}

1. Sociedade Brasileira de Pediatria (SBP). I Congresso Brasileiro de Médicos Residentes em Pediatria [Internet]. Rio de Janeiro (RJ): SBP; 2010; [acesso em 2021 Jun 16]. Disponível em: https://www.sbp.com.br/imprensa/ detalhe/nid/i-congresso-brasileiro-de-medicos-residentes-em-pediatria/

2. Sociedade Brasileira de Pediatria (SBP). Internacionalização da revista Residência Pediátrica é meta para 2017 [Internet]. Rio de Janeiro (RJ): SBP; 2016; [acesso em 2021 Jun 16]. Disponível em: https:// www.sbp.com.br/imprensa/detalhe/nid/internacionalizacao-da-revista-residencia-pediatrica-e-meta-para-2017/
3. Revista Residência Pediátrica (RP). Facebook [Internet]. 2021; [acesso em 2021 Jun 16]. Disponível em: https://www.facebook.com/ revistaresidenciapediatrica/

4. Revista Residência Pediátrica (RP). Twitter [Internet]. 2021; [acesso em 2021 Jun 16]. Disponível em: https://twitter.com/ResidPediatrica

5. Revista Residência Pediátrica (RP). Soundcloud [Internet]. 2021 [acesso em 2021 Jun 16]. Disponível em: https://soundcloud.com/ residenciapediatrica

6. Revista Residência Pediátrica (RP). LinkedIn [Internet]. 2021; [acesso em 2021 Jun 16]. Disponível em: https://www.linkedin.com/company/residenciapediatrica/

7. Revista Residência Pediátrica (RP). Instagram [Internet]. 2021; [acesso em 2021 Jun 16]. Disponível em: https://www.instagram. com/residenciapediatrica/

8. Revista Residência Pediátrica (RP). YouTube [Internet]. 2021; [acesso em 2021 Jun 16]. Disponível em: https://www.youtube.com/channel/UCnZOkNqFAt93euhn2xNd5IA 